\title{
Delo s starostniki
}

\author{
Andrej Berdajs \\ Univerza na Primorskem, Pedagoška fakulteta
}

\section{Staranje prebivalstva}

Fenomen staranja prebivalstva $-\mathrm{z}$ večanjem deleža starih ljudi $-\mathrm{v}$ razvitih državah poteka že desetletja. Tudi populacija starih se stara - vedno več je visoko starih ljudi. Spreminjajo se tudi razmerja med ekonomsko aktivnimi in vzdrževanimi člani družbe. Danes imamo približno $17 \%$ populacije, ki je starejša od 65 let. Demografske projekcije evropskega statističnega urada pa predvidevajo, da se bo v naslednjih desetletjih ta delež povečal na $30 \%$. Stalnica, ki jo opazimo ob pregledu statističnih podatkov o starih ljudeh, je, da ženske živijo v povprečju 10 let dlje kot moški. Pečjak (2007) ugotavlja, da je bila pred dvema desetletjema povprečna starost oskrbovancev v domovih za starejše 70 let, danes pa je 80.

M. Šircelj (2009) pravi, da se v razvitem svetu delež starega prebivalstva veča, ob tem da se veča tudi delež visoko starih. Kot vzroke za tako stanje navaja: zmanjševanje rojstev, zmanjševanje umrljivosti in selitve.

A. Sinjur (2010, str. 59) pravi, »da so selitve (migracije) zelo kompleksen globalen pojav, s katerim se srečujejo vse države po svetu. Države so tako lahko izvor migracij, prehodni cilji potovanja, mesto priselitve, po navadi celo vse troje skupaj«.

Selitve, največkrat zaradi ekonomskih in političnih vzrokov, imajo seveda dve posledici: tam, od koder se ljudje odseljujejo, to povzroča staranje populacije; na območjih, kamor se ljudje priseljujejo, pa to povzroča pomlajevanje populacije. S spreminjanjem deleža starih ljudi se spreminja tudi 
odnos do njih. Starih je bilo včasih manj, bili so deležni spoštovanja zaradi znanja in izkušenj. Danes so bolj cenjeni mlajši, ker jih je malo in se lažje prilagajajo tehnološkemu razvoju (Šircelj, 2009). Sedmak (2005) opozarja, da lahko migracije ljudi v Evropi nekaj časa amortizirajo povečevanje populacije starih in dajo možnost za odlašanje s spremembami, ki jih v organizaciji družbe ta pojav terja. Slej ko prej pa se bo potrebno soočiti z naslednjimi spremembami in dejstvi:

- podaljševanje delovne dobe (tudi zaradi lastne želje delovnih ljudi);

- vedno večji delež starejšega prebivalstva, ki ima porabniško vedenje;

- $\quad$ staranje prebivalstva ne bo prizadelo vseh držav Evropske unije v istem času;

- preprečevanje izključenosti starejših in njihovo vključevanje $\mathrm{v}$ delo ali celo zaposlitev;

- omogočiti starejšim dostop do primernih prebivališč, transportov, zdravja, oskrbe, pa tudi izobraževanja;

- prenašanje znanja za uporabo novih komunikacijskih tehnologij na starejše;

- preprečevanje revščine starejših;

- odstranjevanje zgrešenih klišejev o starosti.

Isti avtor poudarja, da je nova paradigma starosti v pravnih listinah Evropske unije naslednja: temelj je upoštevanje, da sta kakovost življenja in samostojnost mogoča $\mathrm{v}$ vseh življenjskih starostnih dobah; potrebno je preprečevati osamitev ter izključenost starejših ljudi ter krepiti njihovo samozavest; zagotavljati in ohranjati moramo sposobnost starejših za samostojno odločanje ter zagotoviti njihovo občansko in politično vlogo s participacijo v vseh javnih odločitvah.

Prebivalstvo Slovenije je v 20. stoletju naraščalo in leta 2005 preseglo 2 milijona. V demografskih projekcijah se vidi, da se bo čez dve ali tri desetletja začelo zmanjševati in bo okoli leta 2060 na ravni leta 1970. Število tujcev se bo v tem obdobju z 2 \% povečalo na 10,7 \% (Šircelj, 2009).

Poseben problem predstavlja zniževanje deleža prebivalstva, ki je delovno aktivno. Če želimo te posledice zmanjševati, bo potrebno povečati izkoriščenost tega dela populacije oziroma ga povečati na račun kasnejšega prehoda v vzdrževani del prebivalstva (upokojitev). Pečjak (2007) navaja, da čeprav upokojevanje in zdravstveni stroški za starejše ljudi že 40 let 
naraščajo, so v zadnjem obdobju začeli padati. Čedalje manj držav predpisuje obvezno upokojitev pri določeni starosti in uveljavlja se delno zaposlovanje starejših. Tako stari del populacije sam neposredno prispeva k svojemu vzdrževanju.

Tudi v družinskem okolju se spreminjajo sorodstvene mreže. Vedno več imamo sorodnikov v ravni črti (oče, mati, ded, babica) in manj v stranski črti (brat, sestra, bratranec, stric) (Šircelj, 2009).

$S$ področjem dela s starimi ljudmi se ukvarja gerontologija, ki je veda o starosti, staranju in starih ljudeh, ter gerontagogika, ki se ukvarja $\mathrm{z}$ vodenjem in vzgojo starih ljudi. Druga temelji in izhaja iz spoznanj prve. Integralna socialna gerontologija se ukvarja s spoznavanjem zakonitosti staranja in sožitja starih ljudi v okviru družbenega sistema ter $\mathrm{z}$ metodami za doseganje kakovostnega staranja ter bivanja $\mathrm{v}$ družbenem sistemu. Socialna gerontagogika pa obsega delo s posameznikom (po principu zaupnosti, intimnosti), skupinsko delo (na principu skupinskih zakonitosti in dinamike) in skupnostno delo (Ramovš, 2003). Istim vsebinam se s svojo dejavnostjo pridruži tudi socialna pedagogika.

Vse vede, ki se ukvarjajo s starostniki in rešujejo njihove probleme, se bodo morale pospešeno aktivirati in $\mathrm{z}$ upoštevanjem vseh naštetih dejstev sooblikovati družbo in mehanizme, ki bodo starejšim ljudem prijazni.

\section{Starost in staranje}

\section{Starostna obdobja}

Pečjak (2007) navaja, da se staranje začne ob oploditvi. Spremembam, ki jih imamo za staranje, lahko $\mathrm{v}$ prvi polovici človeškega življenja rečemo zorenje, $v$ drugi polovici pa staranje.

Ramovš (2003), A. Kristančič (2005) in V. Hlebec (2009) navajajo, da lahko življenjske cikluse delimo na tri obdobja: mladost (od rojstva do zaključka šolanja), srednja leta (od začetka zaposlitve do upokojitve), starost (od upokojitve do zaključka življenja).

Za obdobje starosti je značilno, da človek materialni razvoj vedno bolj prepušča mlajšim generacijam, njim pa predaja tudi svoje življenjske izkušnje.

Obdobje človekove starosti lahko definiramo tudi na naslednje načine (Ramovš, 2003): kronološka starost (glede na datum rojstva, nekateri za začetek starosti navajajo 65. leto starosti, nekateri že 6o. leto); funkcionalna starost (glede na sposobnost samostojnega opravljanja temeljnih življenj- 
skih opravil); doživljajska starost (glede na to, kako človek sprejema in doživlja svojo trenutno starost).

Čas starosti lahko bolj podrobno razdelimo na: zgodnjo starost (od 65 do 75 let, gre za obdobje, ko se ljudje privajamo na starost, smo še polno dejavni in relativno zdravi); srednjo starost (od 76 do 85 let, $v$ tem času se prilagajamo na upadanje moči in zdravja, na izgubljanje vrstnikov in tudi partnerjev); pozna starost (od 86 let naprej, tu postanemo v večji meri prejemniki pomoči in izvajamo zadnje naloge v življenju).

\section{Stereotipi o staranju}

Pečjak (2007, po Berger in Thompson, 1994) predvideva, da mlajše ljudi stik s starejšimi spominja na umrljivost in zaradi tega razvijejo različne samozaščitne mehanizme, ki se velikokrat izražajo kot stereotipi o starosti, katerih namen je potlačiti misli na starost in smrt.

Kako se nekdo odziva na proces staranja, je odvisno od prožnosti njegovih percepcij o obdobju starosti. Starost lahko interpretiramo kot temačno bodočnost ali pa jo doživljamo kot razširitev in obogatitev življenjskih možnosti (Kristančič, 2005). Avtorica navaja naslednje razloge, zaradi katerih lahko na starost gledamo negativno: pretirano poveličevanje obdobja mladosti; znamenj staranja ne dojemamo kot zorenje, ampak kot bližanje smrti; o staranju ne razmišljamo kot o procesu, ki se začne ob rojstvu, ampak pri 30 ali 40 letih.

Ta strah pred staranjem (gerontofobija) je prisoten tako pri mladih kot pri starih ljudeh. Dejstvo, ki ga morajo prevzeti vse generacije, je, da proces staranja poteka skozi vsa življenjska obdobja.

Pečjak (2007) opozarja na razširjenost ageizma - diskriminacije starostnih skupin prebivalstva. Pogost primer je prisilno upokojevanje, in sicer ne zaradi tehtnih vzrokov (sposobnosti), ampak samo zaradi koledarske starosti. Tudi pri zavarovalnicah naletimo na problem, da imajo starejši ljudje dražje zavarovalnine ali pa so jim celo onemogočene. Tudi banke odklanjajo zadolževanje starejših ljudi. Vsebine ageizma najdemo tudi v razpisih za nova delovna mesta, kjer se brez vsebinske utemeljitve favorizira mlade ljudi oziroma »a priori« odklanja starejše.

\section{Družina in star človek}

Večina ljudi preživi največji del življenja kot član družine. Družina tudi pozitivno vpliva na življenjsko dobo njenih članov. Ljudje, ki živijo v dru- 
žinah, živijo dlje kot samci in ločenci (Pečjak, 2007). Starejšim ljudem v družini vloga dedka in babice velikokrat postane glavna vsebina in smisel njihovega življenja.

Vloga družine, predvsem na področju skrbi za svoje stare člane, se s staranjem prebivalstva spreminja. Najboljša pot, da se družina na novo vlogo pripravi, je stalna in intenzivna komunikacija med njenimi člani, sobivanje in izobraževanje o vsebinah za kvalitetno preživljanje starostnega obdobja življenja (Ramovš, 2003).

Družine iz večinoma dvogeneracijskih prehajajo v trigeneracijske. $\mathrm{V}$ takih družinah je bistveno več možnosti za prenašanje življenjskih spoznanj in izkušenj starejših na mlajše, starim ljudem pa ravno to daje smisel bivanja (Kladnik, 1999).

A. Kristančič (2005) navaja, da bo moral biti odgovor na povečanje števila starih ljudi tudi redefiniranje ${ }^{\mathrm{I}}$ družine, in sicer od družine, ki smo jo poznali in je bila usmerjena predvsem k otrokom, njihovi vzgoji in njihovim potrebam, $\mathrm{k}$ tako imenovani matrični, transgeneracijski ${ }^{2}$ družini, katere usmeritev bo k njenim odraslim in starejšim članom.

Pečjak (2007) opozarja, da starejši zakonci, ki imajo po upokojitvi več časa zase in za stike drug z drugim, lahko zapadejo tudi v naveličanost in pogoste spore. Rešitev je aktivno udejstvovanje $\mathrm{v}$ različnih organizacijah za stare ljudi, ki povečajo pestrost življenja.

Dejstvo je, da tudi starejši ljudje, ki potrebujejo pomoč, kot člani družine participirajo k njenem funkcioniranju. To njihovo sodelovanje ali udeležba da starim ljudem občutek koristnosti in jim dviguje pozitivno samopodobo. Pomembno je tudi, da imajo stari ljudje v krogu družine občutek varnosti. Mlajši člani v družini pa imajo možnost učenja na podlagi prenosa izkušenj starejših. V tem sodelovanju med generacijami pride do izraza pravilo, da ima vsaka generacija več nečesa, kar drugi primanjkuje.

\section{Potrebe v starosti}

Ramovš (2003) trdi, da človek bolj ko je star in zrel, bolje prepoznava svoje potrebe, kakor tudi možnosti, ki jih ima za njihovo zadovoljevanje. Med temeljnimi potrebami izpostavlja tisto po materialni preskrbljenosti, pri kateri je pomembno, da je vir lastno delo (trenutno ali minulo) - največkrat pokojnina oziroma če je ni, socialna pomoč.

1 Ponovna določitev razmerij, pristojnosti, vrednot in prioritet.

2 Družina, ki povezuje več generacij. 
Prav tako starejši ljudje ne smejo pozabiti na ohranjanje telesne, duševne in delovne svežine (to so temeljne vrednote za doseganje kvalitetne starosti, predvsem zato, ker se naravno $\mathrm{z}$ leti zmanjšujejo; ravno zaradi tega jim je potrebno posvečati več pozornosti; stalno gibanje, zdrava prehrana, življenje s ciljem, ustvarjalno delo s harmonijo osebnega ritma; vse to da efektivne rezultate, če je nastavek postavljen $\mathrm{v}$ prejšnjih življenjskih obdobjih).

Potreba po soljudeh je važna v vseh življenjskih obdobjih, njen pomen pa še poraste v starosti. Star človek še bolj potrebuje osebni stik s človekom, ki ga ima za svojega. Prav tako je nezanemarljiv osebni, kožni kontakt z bližnjo osebo. Osamljenost je predvsem v starosti lahko najhujša stiska, zato so pravočasne aktivnosti za ohranjanje in obnavljanje socialne mreže ena od poglavitnih nalog v vseh življenjskih obdobjih.

Prav tako je staremu človeku v večji meri kot mlademu pomembno predajanje življenjskih izkušenj in spoznanj mlajšim generacijam. To je osnovno dejstvo, na podlagi katerega star človek svoje življenje dojema kot nekaj vrednega. Ugotovljena je neposredna povezava med lastnim sprejemanjem novih znanj in spoznanj in med dajanjem svojih izkušenj drugim.

Dojemanje pomena vseživljenjskega učenja je pomembno, tako na področju intelektualnega izobraževanja kot socialnega učenja. Na podlagi novih možnosti v percepcijah sveta in soljudi, stari ljudje okrepijo potrebe po doživljanju smisla lastnega življenja.

Sprejemanje človeške onemoglosti tako s strani starega človeka kot tudi s strani svojcev ali negovalcev je pogoj, da si star človek dopusti predstavo, da je oslabljen in potreben pomoči. Potreba po negi ob onemoglosti ne sme biti razlog za zapiranje pred ljudmi in beg v osamljenost.

Omeniti velja tudi potrebo po nesmrtnosti. To, da se bodo potomci človeka spominjali (grob), da bodo ostala njegova realizirana dela, marsikomu pomeni važno motivacijo. Do neke mere (ali tudi v celoti) jo lahko zamenja vera $\mathrm{v}$ življenje po smrti.

Zavedanje vsebine potreb starega človeka mora biti osnova za usmerjanje dejavnosti in predvsem vzpostavljanje medčloveških odnosov v prejšnjih obdobjih življenja. A. Kristančič navaja (2005), da ima vsaka generacija, ki se postara, povsem drugačne potrebe, zmožnosti, sposobnosti in cilje.

Eden od faktorjev, ki pripomorejo k bistvenemu zvečanju možnosti za kvalitetno staranje, je izobraževanje starejših. Jelenc Krašovec in Kump (2009) omenjata naslednje razloge za motivacijo starih ljudi za izobraževanje: sociološke razloge (izobraževali so se že v mladosti, želijo zapolniti 
svoj prosti čas); psihološke razloge (temeljijo na osebnih značilnostih posameznika in njegovih kognitivnih zmožnostih) ter ekonomske razloge (pri teh je važno, da stroški izobraževanja ne smejo biti ovira). Kot najpomembnejši razlog, da se starejši ljudje vključijo v izobraževalne procese, se pokaže izobraževanje, ki so ga posamezniki že opravili v mladosti.

\section{Kakovostna starost}

Starost - tretje življenjsko obdobje - je čas, ko lahko človek družbi in bližnjim vrača znanje, svoje vire in izkušnje, ki jih je nabral skozi lastne življenjske dogodke. Tendenca starih ljudi mora biti kakovostno preživetje obdobja starosti, ne kot doživljanje nečesa neprijetnega. Dojemanja starosti večinoma izhajajo iz izkušenj, ko ljudje opazujemo stare ljudi in za nekoga zaključimo, da je (ali ni) tak, kot se nam zdi, da bi bilo idealno.

Preseči moramo stereotipno dojemanje starosti. Izhodišča za kakovostno preživljanje starosti temeljijo na doseganju osebne povezanosti med mlado, srednjo in staro generacijo, na tem, da stara generacija sprejema svoje obdobje in da se že srednje generacije pripravljajo na starost. Ob tem moramo preprečiti marginalizacijo starosti in doseči, da se družba v celoti pripravlja na povečanje deleža stare generacije (Ramovš, 2003).

Isti avtor tudi opozarja, da morajo stari ljudje preseči strah pred starostjo, ne smejo si pa zakrivati oči pred neizbežnimi dejstvi, kot so različni problemi, ki izhajajo iz pokojninskega sistema, ki ne pušča pretirano veliko prostora za različne aktivnosti večini starostnikov. Te stvari je potrebno sprejeti in najti poti ter načine, kako z njimi kljub vsemu živeti. Sprejetje starosti mora biti zavestna odločitev. Vsak posameznik si mora najti primeren način staranja na podlagi lastnih intelektualnih in emocionalnih zavedanj. Vsak si mora s pomočjo doživljajskega (vzori, meditacija ipd.) in socialnega (skupine, komunikacija ipd.) učenja najti svoj način bivanja $\mathrm{v}$ obdobju starosti in svoj prostor pod soncem.

A. Kristančič (2005) pa pravi, da moramo na dejstvo, da se življenjska doba ljudi daljša, odgovoriti z naslednjimi aktivnostmi: odpraviti moramo strah pred staranjem; premočrtno življenjsko načrtovanje moramo zamenjati s cikličnim; ustvariti je potrebno nove oblike družinskih odnosov (glede na vedno večji razpon generacij, ki v nekem trenutku sobiva); zmanjšati je potrebno pogostnost kroničnih bolezni v visoki starosti; prav tako moramo organizirati dejavnosti, ki bodo starejšim ljudem omogočala udobje, zadovoljstvo in bodo ustrezala njihovim zmožnostim ter s sožitjem generacij ustvariti socialni sistem, ki bo za vse pravičen. 
Ista avtorica kot zelo pomembno komponento izpostavlja še načrtovanje življenja posameznika in dogodkov v njem. Staro, tradicionalno linearno načrtovanje življenja je bilo predvidljivo: $\mathrm{v}$ določenem starostnem obdobju je bil čas za točno določene dejavnosti in dogodke (šolanje, delo, poroka, družina ipd.). Podaljševanje življenja in daljše ohranjanje vitalnosti pa terja ciklično načrtovanje življenjskih aktivnosti in dogodkov. Elementi življenjskih obdobij, kot so družina, izobraževanje, delo, rekreacija, prosti čas, prostovoljno delo, se prepletajo pri vsakem človeku tako, da doseže ubranost s samim seboj v odvisnosti od svojega temperamenta in zmožnosti. S tem vsak doseže večjo kvaliteto življenja. Še posebej to velja za drugo polovico življenjskega obdobja.

Nujno je, da vsak človek utrjuje in sprejema svojo samopodobo v zrelih letih ter da sprejema spremembe lastnega telesa. Starost je življenjsko obdobje, ki je seveda različno od mladosti in srednjih let, ni pa manj vredno in manj smiselno.

Človek mora že v obdobju srednjih let začeti aktivnosti, s katerimi nadaljuje tudi, ko vstopi v obdobje starosti. Ramovš (2003) opozarja, da mora biti pozoren predvsem na naslednja področja: na vzpostavitev povezave med vsemi tremi generacijami (mlado, srednjo in staro); na konstantno skrb za zdravo življenje in zdravje; na skrb za ohranjanje in krepitev osebne svobode in samostojnosti odločanja; na ohranjanje in krepitev medčloveških odnosov $\mathrm{z}$ različnimi ljudmi; na konstantno učenje novih dejstev in spretnosti ter ustvarjalnost ter na zavedanje vrednosti in smisla preteklosti, sedanjosti in prihodnosti svojega življenja.

Ramovš kot življenjske naloge, ki si jih mora zastaviti star človek s ciljem, da bo doživel kvalitetno starost, našteva naslednje: dejavno življenje (stalno ohranjanje telesne, duševne in delovne svežine ter povezanostmi z ljudmi); preprosto življenje (umirjene aktivnosti, večja osebna svoboda pri njihovem načrtovanju, prepuščanje skrbi za materialno preskrbo srednji generaciji); sproščeno življenje (sprejeti je potrebno smiselno stališče do preteklosti, sedanjosti in prihodnosti); vedro življenje (z nadaljevanjem vseživljenjskega učenja in predajanjem življenjskih izkušenj mlajšim); samostojno življenje (predvsem po izgubi življenjskih sopotnikov) in dozorelo življenje (opravljanje zadnjih življenjskih nalog).

\section{Socialne mreže $v$ starosti}

V vseh življenjskih obdobjih, še bolj pa v starosti, je pomembna človekova vpetost v socialno mrežo, kakor tudi doživljanje lastne osebne intimnosti (Ramovš, 2003). 
Socialna omrežja so pomemben dejavnik zdravja (ne le starejših ljudi). Zlasti je pomembna stalna socialna opora, ki omogoča posamezniku občutek pripadnosti in intimnosti. Ta se realizira večinoma s partnerjem, $\mathrm{z}$ drugimi družinskimi člani, s sosedi, s člani skupnosti ali s člani organizacije, $v$ katero se posameznik vključuje (Pahor, Domanjko in Hlebec, 2009).

Socialna opora je največji blažilec vseh življenjskih stresnih dogajanj. Njeno pomanjkanje ali celo popolna odsotnost vedno vodi v depresijo in je razlog zanjo. Pomen medčloveških odnosov za vsakega v vseh življenjskih obdobjih (še bolj pa v starosti) je neprecenljiv. Partnerski odnosi, ljubezen in intimnost so bistveni faktorji, ki vplivajo na kvaliteto življenja, predvsem pa nam pomagajo premagovati različne ovire in težave $\mathrm{v}$ vseh življenjskih obdobjih.

Kladnik (1999) navaja, da v socialnih mrežah sicer prevladujejo funkcionalni odnosi. Bistveno bolj pa socialni stiki zadovoljijo človeka, če gre za temeljni odnos z neko osebo, kar omogoča občutek varnosti. Poglobljeni odnosi omogočajo spontanost in so osnova za socialno učenje.

Pomembne so vezi ne le $\mathrm{v}$ isti generaciji, ampak tudi tako imenovana generacijska zavezništva, kjer se tkejo vezi med zastopniki različnih generacij s ciljem, da lahko ena generacija prevzame odgovornosti in skrbi za druge generacije. Vse tri generacije (mlada, srednja in stara) so sistemska celota in so v stalni komplementarnosti (Ramovš, 2003). Avtor opozarja na pomen medgeneracijskega sodelovanja in programov, ki bodo pomagali konstruirati kvaliteten sistem za življenje starih ljudi. Sem sodi ozaveščanje prebivalstva o pomenu in komponentah kakovostnega staranja in nujnosti priprave na starost $\mathrm{v}$ prejšnjih življenjskih obdobjih, usposabljanje za čas po upokojitvi, usposabljanje družin, v katerih živijo stari ljudje, ter usposabljanje starejših za boljše razumevanje mlajših.

A. Kristančič (2005) poudarja, da mora vpetost v socialno omrežje in ohranjanje stikov vsak posameznik planirati in izvajati aktivnosti skozi celotno življenjsko obdobje. Važno je obvladovanje komunikacije (tako $\mathrm{z}$ drugimi kot s samim seboj). Pomembna je stalna notranja komunikacija posameznika in samoevalvacija aktivnosti in razmišljanj. Nezanemarljiv element dobre in kvalitetne komunikacije je dobro poslušanje in slišanje.

Ramovš (2003) opozarja na socialne motnje, na katere naletimo pri starih ljudeh. To so velikokrat pretirana črnogledost, zagrenjenost in sitnoba. S strani bližnjih ali oseb, ki skrbijo za starega človeka, jih je potrebno sprejeti in jih blažiti s pravilno komunikacijo. Nasploh je vedno najboljše 
za preprečevanje in blaženje socialnih motenj v starosti dobra, po možnosti medgeneracijska, komunikacija.

Starost in staranje sta kategoriji, ki ju je potrebno upoštevati kot sestavna dela življenja slehernika. S splošnim vedenjem o osnovnih zakonitostih tega življenjskega obdobja bomo lahko bistveno zmanjšali (ali izkoreninili) v družbi zasidrane stereotipe o staranju. Lahko bomo redefinirali družino kot najbolj aktivno osnovno celico za družbeno integracijo starostnikov. Upoštevanje potreb starejših ljudi ter predvsem omogočanje njihovega vpetja v socialne mreže so temelj za kakovostno starost.

\section{Obravnava starostništva in institucije za socialno varstvo} starejših ljudi

Temeljno poslanstvo države je med drugim organiziranje socialne politike. Zaradi omenjenega dejstva, da se delež starih ljudi v družbi povečuje, mora država krepiti pogoje, $s$ katerimi bo ta del populacije imel možnosti, da obdobje starostništva kvalitetno preživi in da ob tem tudi družbi in mlajšim generacijam uspešno predaja svoje bogate življenjske izkušnje.

V Sloveniji se je relativno zgodaj, že leta 1963, začela znanstvena obravnava staranja ljudi. Takrat je bil ustanovljen Gerontološki inštitut. Žal se je v kasnejšem obdobju v prejšnji državi dejavnost zožila le na področje geriatrije (medicinske obravnave starostnih težav), ki se je kasneje še reduciralo na obravnavo bolezni srca in ožilja (Sedmak, 2005).

Cilj današnjih aktivnosti v politiki socialnega varstva starih ljudi ni le podaljševanje življenjske dobe, ampak podpiranje kakovosti v tem življenjskem obdobju. S tem ciljem je bila ustanovljena Univerza za tretje življenjsko obdobje in organizirala se je oskrba za stare ljudi na domu.

Da omogoči starim ljudem možnosti kakovostnega staranja, mora država kot nosilka socialne politike poskrbeti predvsem za naslednje programe in konkretne vsebine v socialnih mrežah (Ramovš, 2003):

- programi za kakovostno življenje samostojnih starejših ljudi,

- programi za delno pomoč starejšim ljudem,

- programi za popolno pomoč opešanim starejšim ljudem.

Izvedba teh programov je možna na naslednje načine:

- javni državni programi in državna podpora družinam, ki skrbijo za stare ljudi, ter državna podpora civilnim programom,

- civilni in zasebni neprofitni - prostovoljni programi, 
- tržni programi.

M. Nagode (2009) navaja, da je v Sloveniji v trenutnem modelu skrbi za stare ljudi država obdržala dominanten položaj kot financer izvajanja različnih oblik oskrbe, ne pa kot izvajalec. Poleg države se kot ustanovitelji institucij za varstvo in oskrbo starih ljudi pojavljajo tudi zasebne neprofitne organizacije (največ cerkev), pa tudi zasebne profitne organizacije. Veliko jih ima $\mathrm{z}$ državo sklenjeno koncesijsko pogodbo, kar lahko neposredno vpliva na konstantnost in strokovnost njihovega delovanja.

V domovih za ostarele je trenutno manj kot tretjina starih ljudi, ki potrebujejo pomoč. Povečuje se organiziranost in ponudba vsebin za stare ljudi s strani civilne družbe. To so različna društva za aktivnosti starih ljudi, veliko je tudi samoorganiziranja starejših v svoje lastne organizacije, v porastu je organiziranje mreže za medgeneracijsko sožitje.

Pri oskrbi starih ljudi je potrebno upoštevati, da so zelo heterogena skupina ljudi. Sestavljajo jo lahko starejši toda relativno sposobni, tisti z manjšimi ali večjimi zdravstvenimi težavami, dementni, invalidi, tujci ipd. (Mali, 2008).

V. Miloševič Arnold (200o) povzema najpomembnejša izhodišča za sestavo konceptov uspešnega dela s starimi ljudmi:

- razumevanje razvojnih faz staranja,

- upoštevanje življenjskih izkušenj in vlog, ki so jih doživeli stari ljudje,

- razumevanje perspektiv starih ljudi,

- ugotavljanje in upoštevanje funkcionalnih sposobnosti starih ljudi,

- $\quad$ poznavanje njihove dinamike v družinskem življenju,

- prepoznavanje njihovih potreb,

- zmožnost komuniciranja v govorici starejših,

- trdno prepričanje v neodvisnost starih ljudi,

- razumevanje smrti in umiranja.

Na teh izhodiščih morajo temeljiti vse sistemske in zakonodajne rešitve, ki jih bo družba sprejela, da bo ne samo omogočila, ampak tudi izboljšala socialno varstvo za starejše ljudi. 


\section{Oblike socialnega varstva starejših ljudi}

J. Mali (2009) navaja, da za Slovenijo po tradiciji velja, da je na področju varstva starejših zanjo značilna institucionalna skrb za stare ljudi - domovi za starejše. Po letu 2000 se v organizaciji domov za ostarele doktrina od izrazito medicinskega modela oskrbe premakne v socialni model s poudarjenim individualnim pristopom do posameznika. Toda trenutna utečena praksa oskrbe $\mathrm{v}$ domovih za starejše je prilagojena starim bolnim ljudem. Stanovalci so definirani kot pasivni prejemniki pomoči (za njih se praviloma uporablja poimenovanje pacienti).

Pečjak (2007) opozarja, da se stari ljudje zelo težko prilagajajo spremembam. Preselitev v dom za stare ljudi pa to nedvomno je. Težko se privadijo na veliko število starih ljudi na enem mestu, na pomanjkanje možnosti biti sami ali vzpostaviti pristne medosebne stike $\mathrm{z}$ drugimi prebivalci $\mathrm{v}$ domu.

S predlagano zakonodajo, tudi po zgledu ostalih držav Evropske unije, naj bi v prihodnje oskrbo v domovih za ostarele izrazito diferencirali na specializirane domove za oskrbo starih ljudi, ki potrebujejo zdravstveno nego, na domove za oskrbo starih ljudi z demenco ter na domove za oskrbo starih ljudi, ki so samostojni in si želijo ter potrebujejo zgolj družabništvo.

Splošnih domov za ostarele, kot jih večinoma poznamo danes, v prihodnje naj ne bi bilo.

V privatni sferi na področju institucionalnega varstva starejših ljudi se poudarja žal le materialni standard oskrbe in ni poudarka na drugih komponentah kvalitete življenja (Mali, 2009).

Poleg oskrbe v domovih za ostarele je socialno varstvo za stare ljudi pri nas organizirano tudi v naslednjih oblikah: pomoč na domu; družinska oskrba starejših družinskih članov; pomoč starim ljudem na daljavo in dnevni centri.

Tudi tu je vključena država, ki podpira razvoj institucionalne mreže, dnevnih centrov in pomoči na domu. Pomoč je sistemsko regulirana in ima naslednje značilnosti (Nagode, 2009):

- varnost (predvidljivost, zanesljivost reagiranja),

- sociabilnost (domačnost, zaupanje, empatija in enakost $v$ odnosih),

- ekonomičnost (cenovna sprejemljivost storitev).

Pomembno je, da je pomoč profesionalna in da jo izvajajo strokovno usposobljene osebe. Ugodno je tudi, da so te komponente pomoči sta- 
rim ljudem komplementarne neformalni pomoči s strani družine, prijateljev in prostovoljcev. Ramovš (2003) kot možne organizacijske oblike navaja naslednje vrste pomoči starim ljudem: pomoč in nega na domu, pomoč družinam, ki skrbijo za svojega ostarelega člana, varovana in prilagojena stanovanja, dnevno varstvo za stare ljudi, gerontološki centri, pomoč pri samostojnosti starega človeka s tehničnimi pripomočki, domovi za stare ljudi, stanovanjske skupine za stare ljudi in oskrbniške družine.

Za doseganje ciljev zastavljenih za kvalitetno starost pa omenja naslednje programe:

- $\quad$ starostna pokojnina;

- programi za samostojne stare ljudi (zaposlitev in delo za starejše, medsebojno povezovanje starostnikov, izobraževanje za stare ljudi, šport in rekreacija, potovanja, počitnice in razvedrila, medgeneracijski projekti, priprava na upokojitev, stanovanjske skupine);

- $\quad$ pomoč na domu za delno samostojne stare ljudi (usposabljanje za člane družin s starejšim članom, pomoč in nega na domu, preprečevanje nasilja nad starimi ljudmi - zagovorništvo, pomoč na daljavo (pošta, elektronska pošta, telefon), varovana stanovanja);

- programi za popolno oskrbo (domovi za stare ljudi, oskrbniške družine, dnevno varstvo, hišne skupnosti);

- $\quad$ programi za pomoč ljudem v sklepni fazi življenja;

- programi za ozaveščanje prebivalstva o kakovostnem staranju.

\section{Pomoč starim ljudem na domu}

Kot smo že omenili, je cilj socialne politike Evropske unije ustvariti pogoje, da bi se čim večjemu številu starih ljudi omogočilo, da čim dlje v obdobje starosti ostanejo v domačem, če se le da, v družinskem okolju. Seveda morajo biti ustvarjeni pogoji, ki jim bodo nudili to tako, da bodo v čim večji meri samostojni, varni in da bo njihovo življenje kakovostno.

Pomoč na domu je temeljna socialno varstvena storitev, ki jo mora po veljavni zakonodaji organizirati občina in finančno pokriti vsaj polovico stroškov.

$\mathrm{V}$ večini to pomoč izvajajo centri za socialno delo in domovi za starejše, nekaj pa je tudi profitnih organizacij s koncesijo. Pomoč na domu obsega pomoč pri temeljnih dnevnih opravilih, gospodinjsko pomoč in pomoč pri ohranjanju socialnih stikov. 


\section{Družinska oskrba starejših družinskih članov}

V družinah so oskrbovalci starih družinskih članov predvsem osebe, ki so sorodstveno povezane z osebo, ki jo oskrbujejo. Lahko (večinoma) prebivajo na skupnem naslovu ali pa drugje. Praviloma so to osebe, ki nimajo formalno pridobljene izobrazbe ali znanj s področja oskrbe starejših ljudi. Seveda je v veliki večini primerov taka oskrba brezplačna.

S. Hvalič Touzery (2009) povzema, da tako oskrbo sestavljajo: nega, pomoč pri ohranjanju in vzpostavljanju socialnih stikov ter gospodinjska pomoč.

Družinska oskrba starih družinskih članov je lahko pomemben vidik družinskega življenja, ki da možnost, da pri njej sodeluje več družinskih članov različnih generacij. S. Hvalič Touzery (2009) navaja, da med družinskimi člani, ki izvajajo družinsko oskrbo, prevladujejo osebe ženskega spola (približno dve tretjini) ter da se na ta način v Sloveniji oskrbuje več starih ljudi, kot jih je oskrbovanih $\mathrm{v}$ ustanovah in različnih programih javne mreže.

Najpomembnejši razlogi, da se ljudje odločijo za vlogo oskrbovalcev starih ljudi, so čustvene vezi, občutek dolžnosti in moralna odgovornost. Materialne ugodnosti praviloma niso razlog za take odločitve (Hvalič Touzery, 2009).

Izvajanje družinske oskrbe za starega družinskega člana ima lahko za družino in oskrbovalca tako pozitivne kot negativne posledice. Med pozitivne štejejo povečanje medsebojne povezanosti, večanje občutka varnosti, rast strpnosti in odkrivanje novih notranjih moči pri posameznikih, med negativnimi pa lahko omenimo časovno stisko vsakdanjega življenja, preobremenjenost posameznih družinskih članov, ki lahko vodi v konflikte znotraj družine.

S. Hvalič Touzery (2009) navaja, da so oskrbovalci, ki skrbijo za stare ljudi v krogu družine, izrazili tudi probleme, s katerimi se soočajo, in sicer: zmanjšanje možnosti ali celo popolnoma nemogoče najti čas za lasten oddih ali dopust, pomanjkanje možnosti pridobiti svetovanje s strani strokovnjakov ter da se velikokrat oskrba reducira na eno samo osebo, ki pogreša pomoč ostalih sorodnikov.

V strategiji razvoja socialne politike v državah Evropske unije je tendenca, da bi čim večje število starih ljudi dobilo oskrbo na domu. Ob tem je nujno predvideti in realizirati strokovno in sprotno pomoč ter svetovanje družinam, ki tako oskrbo izvajajo ali se pripravljajo nanjo. 


\section{Pomoč starim ljudem na daljavo}

Pomoč starim ljudem na daljavo izvajajo predvsem centri za pomoč. Temelji na telekomunikacijski povezavi med starim človekom in centrom, in sicer kot enosmerni alarm, ki ga sproži star človek ob stiski, ali pa kot dvosmerna telefonska linija, ki omogoča komuniciranje med starim človekom in uslužbencem centra.

\section{Dnevni centri}

Dnevni centri so namenjeni starim ljudem, ki zaradi različnih razlogov potrebujejo pomoč, varovanje ali nadzor. Njihova sposobnost samostojnosti in zdravstveno stanje pa nista tako okrnjena, da bi potrebovali stalno oskrbo in zdravstveno nego. $\mathrm{V}$ dnevnih centrih imajo stari ljudje možnost komunikacije $\mathrm{z}$ vrstniki ali zaposlenimi (prostovoljci) in se vključijo $\mathrm{v}$ različne rekreacijske ali kulturne aktivnosti. Večinoma so organizirani v okviru domov za stare ljudi. Dnevni centri so velikokrat dober komplement družinski oskrbi starih ljudi, saj omogočajo občasno razbremenitev drugih družinskih članov.

V različnih oblikah socialnega varstva starejših ljudi je v naši družbi še kar nekaj rezerv. Morda je tu marsikje možnost za nove podjetniške spodbude strokovnjakov, nova zaposlovanja in ne nazadnje tudi možnosti za aktivno dejavnost zmožnih starejših ljudi.

\section{Vloga socialne pedagogike pri delu s starejšimi ljudmi}

Cilj vseh socialnopedagoških intervencij je nuditi pomoč ljudem različnih starosti v razvojnih krizah ter konfliktih, stresnih in življenjsko obremenjujočih situacijah s ciljem, da se integrirajo $v$ socialno okolje s pomočjo pedagoških pristopov, metod in strategij (Skalar, 2006).

Socialna pedagogika je usmerjena $\mathrm{k}$ reševanju problemov, ki nastajajo v vseh življenjskih obdobjih. Predvsem se usmerja na tiste dele prebivalstva, ki jim lahko pomaga pri integraciji v družbo. Rast deleža starejših ljudi nas začenja usmerjati tudi k delu $\mathrm{z}$ njimi.

Socialnopedagoško delo s starimi ljudmi vsebuje:

- pomoč tistim, ki nimajo zadosti osebnih in materialnih sredstev za upravljanje $\mathrm{z}$ življenjem;

- pomoč tistim, ki so v kritičnem obdobju življenja;

- aktivnosti, ki povečujejo klientove možnosti. 
$\mathrm{V}$ socialnopedagoškem delu delujemo preventivno, kompenzatorno, razvojno in integrativno. Vedno moramo upoštevati življenjsko okolje oseb, s katerimi delamo. Temelj socialnopedagoškega delovanja je osebni odnos s »klientom«. Na ta odnos vplivamo s svojo osebnostjo in usposobljenostjo. Pri socialnopedagoškem delu vedno izhajamo iz posameznika in njegovega socialnega okolja - tudi naše delovanje je usmerjeno tako, da bo »klient« obvladoval življenjske probleme v lastnem življenjskem kontekstu.

Cilji delovanja in interveniranja socialnih pedagogov so, da ljudem, ki jih v različnih življenjskih obdobjih bremenijo in ovirajo različne krize ter problemi, nudijo pomoč za reševanje takih situacij in jim pomagajo pri uspešni integraciji v njihovo socialno okolje. Socialni pedagog mora biti vedno odprt za socialno učenje, za reflektiranje lastnega dela in mora stalno razvijati lastno občutljivost za socialna dogajanja.

Razlogi za usmeritev delovanja socialnih pedagogov na področje dela s starejšimi, če jih še enkrat povzamemo, so naslednji:

- $\quad$ povečevanje deleža te populacije v družbi;

- $\quad$ porast stisk in patologije, vezane na starostniško obdobje ljudi;

- potrebe po učenju starejše populacije za lažje (ali sploh) dojemanje aktualnega sveta in odnosov v družbi.

V Etičnem kodeksu delavcev na področju socialne pedagogike (2006) je poudarjeno, da socialni pedagogi izhajamo iz specifik posameznika, prizadevamo si za njegovo vključevanje v okolje, ga opolnomočimo in usmerjamo $\mathrm{k}$ polnejšemu uresničevanju njegovih potreb in razvoju njegovih potencialov.

Delo socialnega pedagoga temelji na osebnem odnosu do obravnavane osebe. Le tako dobimo možnost, da vzpostavimo medij, ki omogoča vplivanje in učenje.

Vse našteto vodi $\mathrm{k}$ temu, da se socialni pedagogi aktivno vključimo kot členi verige, ki prispeva h kvalitetnemu življenju starejših ljudi. Lahko smo tvorci in vzdrževalci socialnih mrež za starejše ljudi in predvsem tisti, ki bomo ciljne skupine ozaveščali o pomenu in nujnosti takih mrež. Tudi $\mathrm{v}$ domovih za starejše je ravno socialni pedagog tista oseba, ki bo usmerjenost oskrbe za stare ljudi od izrazito medicinskega modela premaknila na bolj socialno področje. Enako velja za stanovanjske skupine, pomoč starim ljudem na daljavo ter za delovanja v dnevnih centrih za stare ljudi. 
Delo socialnega pedagoga $\mathrm{v}$ domu za starejše ljudi temelji na empatiji, razumevanju in posluhu za specifične probleme starih ljudi ter obsega (Anzeljc, 2012):

- pomoč pri vključevanju v domsko življenje;

- pomoč pri spoznavanju sostanovalcev, osebja in načina življenja ter delovanja doma;

- oblikovanje in ponudba različnih možnosti za participacijo, aktivno udejstvovanje in vpetje v socialne mreže;

- $\quad$ spodbujanje in pomoč pri vključevanju $\mathrm{v}$ domske aktivnosti in povezovanja $\mathrm{z}$ drugimi starostniki;

- oblikovanje možnosti, da se stari ljudje počutijo vredne in koristne;

- povezovanje med starimi ljudmi in svojci;

- $\quad$ pomoč pri vzpostavitvi poznanstev med sostanovalci;

- povezovanje med različnimi socialnimi mrežami (medgeneracijsko sodelovanje);

- $\quad$ biti za stare ljudi tisti, ki je pripravljen poslušati, svetovati in pomagati;

- povezovanje institucije in lokalne skupnosti;

- $\quad$ spodbujanje za udejstvovanje, ki prinese občutek sprejetosti in pripadnosti;

- koordiniranje dela prostovoljcev.

$\mathrm{V}$ enakem smislu je delo socialnega pedagoga orientirano tudi v drugih oblikah pomoči starim ljudem. To omogoča širitev socialnopedagoške paradigme tudi na področja, kjer je do sedaj bila $\mathrm{v}$ manjšini in kjer se $\mathrm{v}$ ne tako daljni prihodnosti odpirajo velike možnosti.

\section{Sklep}

Glede na trenutno stanje naraščanja deleža starih ljudi v družbi, predvsem pa na osnovi demografskih projekcij, ugotavljamo, da bo uspešno delo $s$ starimi ljudmi temelj pri zagotavljanju družbene stabilnosti. Zmanjševanje deleža aktivnega prebivalstva in povečevanje deleža vzdrževanih, višanje starosti za upokojitev, povečevanje delnega zaposlovanja starejših v organizacijo družbe postavlja nova razmerja.

Osnovno izhodišče za boljše in uspešnejše delovanje s starejšimi je bolj poglobljeno vedenje in znanje o različnih možnostih staranja, ki ga morajo 
pridobiti vsi, ki se s tem področjem ukvarjajo. V družbi je potrebno preseči zakoreninjene stereotipe o starosti in o starih ljudeh.

Razumeti moramo, kaj porast deleža starejših pomeni za funkcioniranje družin, ki se iz dvogeneracijskih spreminjajo v trigeneracijske.

Ugotavljamo, da moramo poznati in se zavedati potreb, ki se pojavljajo pri starejših ljudeh in ki so osnova za usmerjanje aktivnosti pri delu s to populacijo. Pri tem moramo izhajati iz vsebin, ki omogočajo starejšim ljudem kvalitetno preživljanje tega življenjskega obdobja.

Starejši ljudje, kot tudi tisti, ki jim pomagajo, morajo biti pozorni predvsem na ohranjanje in razširjanje socialnih mrež, v katere so vpeti posamezniki. Te mreže so pomemben dejavnik zdravja in blažilec različnih življenjskih dogajanj. Pomembne so tako v povezavah oseb istih generacij kot tudi za medgeneracijsko sodelovanje.

Država kot nosilka socialne politike mora $\mathrm{v}$ omogočanju javnih in zasebnih programov ter $\mathrm{v}$ snovanju aktualnih zakonskih okvirov najti odgovore na te razmere in omogočiti razvoj obstoječega sistema.

Bistveni cilj dela s starejšimi ljudmi je povečevanje njihove zmožnosti in sposobnosti za soočanje s težavami, ki se pojavijo v starosti, in uspešno premagovanje problemov.

Zaključujemo, da se lahko konkretno socialnopedagoško delo za starejše realizira tako $\mathrm{v}$ obstoječih institucijah kot v obliki lastne podjetniške iniciative. Pomembno je, da v socialnopedagoške izobraževalne programe vključujemo čim več vsebin, ki so neposredno povezane $z$ delom s starejšimi ljudmi. Hkrati je potrebno ozaveščanje tako socialnih pedagogov kot širše družbe, da sta socialna pedagogika in pomoč ljudem v obdobju starosti kompatibilna.

\section{Literatura}

Anzeljc, N. (2012). Socialne mreže starostnikov in vloga socialnega pedagoga $v$ institucionalnem varstvu (Diplomsko delo). Univerza v Ljubljani, Pedagoška fakulteta, Ljubljana.

Etični kodeks delavcev na področju socialne pedagogike. (2006). V B. Dekleva,

A. Kobolt, Š. Razpotnik, M. Sande, D. Zorc-Maver (ur.), Socialna pedagogika-izbrani koncepti stroke (str. 191-196). Ljubljana: Pedagoška fakulteta. Hlebec, V. (2009). Starejši ljudje v družbi sprememb. Maribor: Aristej. 
Hvalič Touzery, S. (2009). Družinska oskrba bolnih starih družinskih članov. V V. Hlebec (ur.) Starejši ljudje v družbi sprememb (str. 102-124). Maribor: Aristej.

Jelenc Krašovec, S., in Kump, S. (2009). Udeležba starejših odraslih v izobraževanju v Sloveniji. V V. Hlebec (ur.), Starejši ljudje v družbi sprememb (str. 203-220). Maribor: Aristej.

Kladnik, T. (1999). Socialna gerontologija in gerontagogika. Socialna pedagogi$k a, 3(2)$, str. 185-194.

Kristančič, A. (2005). Nova podoba staranja - siva revolucija. Ljubljana: AA Inserco.

Mali, J. (2008). Od hiralnic do domov za stare ljudi. Ljubljana: Fakulteta za socialno delo.

Mali, J. (2009). Spremembe v institucionalnem varstvu starejših. V V. Hlebec (ur.), Starejši ljudje v družbi sprememb (str. 95-108). Maribor: Aristej.

Miloševič Arnold, V. (200o). Profesionalne vloge socialnih delavcev pri delu s starimi ljudmi. Socialno delo, 39(4-5), str. 253-263. Ljubljana: Fakulteta za socialno delo.

Nagode, M. (2009). Organizirana pomoč za stare ljudi, ki živijo na domu: pomoč na domu in varovanje na daljavo. V V. Hlebec (ur.), Starejši ljudje v družbi sprememb (str. 125-138). Maribor: Aristej.

Pahor, M., Domajnko, B., in Hlebec, V. (2009). Spleti zdravja in bolezni: socialna omrežja starejših kot dejavnik zdravja. V V. Hlebec (ur.), Starejši ljudje v družbi sprememb (str. 221-236). Maribor: Aristej.

Pečjak, V. (2007).Fn Psihologija staranja. Bled: samozaložba.

Ramovš, J. (2003). Kakovostna starost. Socialna gerontologija in gerontagogika. Ljubljana: Inštitut Antona Trstenjaka.

Sedmak, M. (2005). Posameznik družba - država - Evropa. V A. Kristančič (ur.), Nova podoba staranja - siva revolucija (str. 197-217). Ljubljana: AA Inserco.

Sinjur, A. (2010). Učenci z imigrantskim ozadjem - politike in praksa učenja maternega jezika učencev imigrantov v nekaterih državah EU. Educa, 19(3-4), 59-69.

Skalar, V. (2006). Štiri desetletja do socialne pedagogike. V B. Dekleva, A. Kobolt, Š. Razpotnik, M. Sande, D. Zorc - Maver (ur.), Socialna pedagogika-izbrani koncepti stroke (str. 191-196). Ljubljana: Pedagoška fakulteta.

Šircelj, M. (2009). Staranje prebivalstva v Sloveniji. V V. Hlebec (ur.), Starejši ljudje v družbi sprememb (str. 15-44). Maribor: Aristej. 